\title{
Echinodermata (Asteroidea, Echinoidea and Holothuroidea) of Mermaid (Rowley Shoals), Scott and Seringapatam Reefs, Western Australia.
}

\author{
Clay Bryce and Loisette Marsh \\ Department of Aquatic Zoology \\ Western Australian Museum, Locked Bag 49, Welshpool, D.C. 6986 Email: clay.bryce@museum.wa.gov.au
}

\begin{abstract}
A survey documenting the diversity and indicative abundance of targeted echinoderms (asteroids, echinoids and holothurians) at Mermaid, Scott and Seringapatam Reefs was conducted in September 2006. Due to logistical constraints species were counted along a single transect furnishing limited scope for statistical analysis. Echinoderms (including some ophiuroids) were collected opportunistically at each station. Fourteen species of echinoderm were collected from the NW atolls for the first time (five species of Asteroidea including a possible new species, six Ophiuroidea and three Echinodea). Voucher specimens of all but the commonest species have been lodged with the Western Australian Museum. The echinoderm fauna of Scott Reef, particularly North Scott Reef, has declined in abundance and species richness since the surveys of the 1980s. This may have been influenced by a significant coral bleaching event in 1998 and subsequent scouring by cyclonic activity. Fishing pressure at South and North Scott Reefs (but not Mermaid Reef) by Indonesian fishers has also had a drastic effect on holothurian populations to the point where oligospermy will be a serious factor.
\end{abstract}

\section{INTRODUCTION:}

In 1986, the Western Australian Museum (WA Museum) published the results of its surveys of the Rowley Shoals, Scott and Seringapatam Reefs (Berry, 1986). Included were the results of the first survey of the echinoderms (Marsh, 1986). There have been no formal biodiversity surveys since that time. Several agencies, including the Australian Institute of Marine Science (AIMS) (Rees et al., 2003) and the Commonwealth Scientific and Industrial Organisation (CSIRO) (Skewes et al., 1999) have undertaken marine resource evaluations, including holothurians (Smith et al., 2005). The WA Museum also undertook a contract rapid assessment survey of the marine resources (including holothurians) of Scott Reef and Seringapatam Reefs and Browse Island in February 2006 (Bryce, 2006). All of these surveys were related to fishing pressure and general stock assessments and did not investigate other echinoderm groups.

Here we report in detail the echinoderms recorded during the 2006 WA Museum survey of Mermaid (Rowley Shoals), Scott and Seringapatam Reefs off the north coast of Western Australia. The information in this paper supersedes that provided in the 2006 unpublished preliminary report (Bryce and Marsh, 2006) of the same survey.

\section{METHODOLOGY}

\section{(see Station and Transect Data in this volume)}

The echinoderm species were recorded, individuals counted and representatives collected from a single transect, which was one of the two mollusc transects at each station. Additional species were also collected generally from the station area. Due to logistical constraints and lack of time in the field the Ophiuroidea were only collected opportunistically and crinoids were omitted from the survey.

The methodology adopted recorded echinoderm diversity with an indication of abundance. The method (described in detail below) varied dependent on whether the station was located on the outer reef slope, in the lagoon or on the reef platform.

A single transect was swum at all stations, except for reef platform stations and the channel drifts. Extra echinoderm records were made throughout the transect swim to increase the biodiversity list; this was accomplished by opportunistic investigations of the areas adjacent to the transect. The diver would periodically mark his current transect position and then explore habitats and features adjacent to the transect. Further investigations were undertaken by a general swim around the station once the transect had been completed. This ensured all depths and 
Table 1 Number of stations sampled for Echinoderms - 1986 and 2006

\begin{tabular}{l|c|c|c|c|c}
\hline & Clerke & Mermaid & Sth Scott & Nth Scott & Seringapatam \\
\hline 1986 Report & 20 & 2 & 12 & 11 & 2 \\
2006 Report & & 16 & 14 & 10 & 5 \\
\hline
\end{tabular}

habitats were represented in the biodiversity list while maximising dive time and completing the transect. The time at each station was limited to approximately one hour of effort, which varied depending on the complexity of the topography, transect length and habitat types encountered.

\section{Outer slope stations:}

A single transect, one metre wide, was swum up-slope from a depth of $20 \mathrm{~m}$ to reef crest at 3 to $4 \mathrm{~m}$. The transect was determined at the surface by lining up the $20 \mathrm{~m}$ station buoy with the two shallower buoys marking the replicated transects of the coral, sponge and crustacean researchers. A transect bearing using an underwater compass was used to keep the diver on course.

As many echinoderms are cryptic, rocks and coral slabs, when abundant, were turned at 20, 15, 10 and $5 \mathrm{~m}$ depth increments along the transect. Where rocks and slabs were few all encountered were turned and investigated. Small sand patches occurring intermittently were raked for echinoid species; larger sand plains were sub-sampled by raking a series of one metre squares at every alternate meter along the transect line. Small hand rakes were used for this purpose.

\section{Lagoon Stations:}

All lagoon stations were centred on coral outcrops or reef edges to maximise habitat diversity. The methodology for these stations differed little from the outer slope stations, except for instances where the required $20 \mathrm{~m}$ starting depth was unobtainable. In these instances, the transect was defined by the distance between the buoys marking the shallow and deep transect series of the coral, sponge and crustacean divers. In this way, the transect ran from deepest to shallowest point and perpendicular to the other transects.

\section{Platform Stations:}

Platform habitats have several zones - outer edge, platform centre and lagoonal edge - and these can be more then a kilometre apart. As such, this macro-habitat was treated as a biodiversity site with no attempt to quantify the echinoderms found.

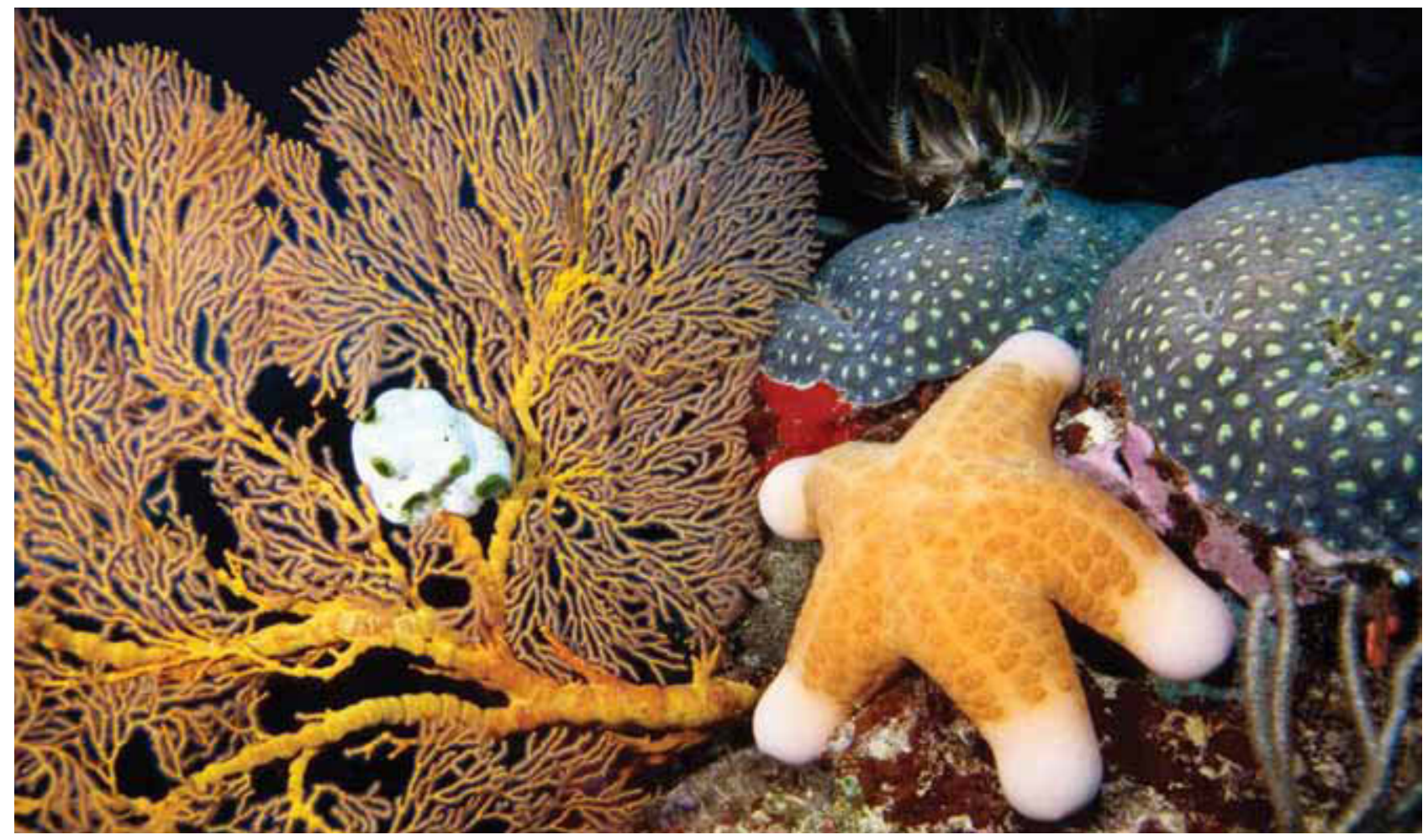

Above: Choriaster granulatus Lütken, 1869 (Photo: Clay Bryce) 

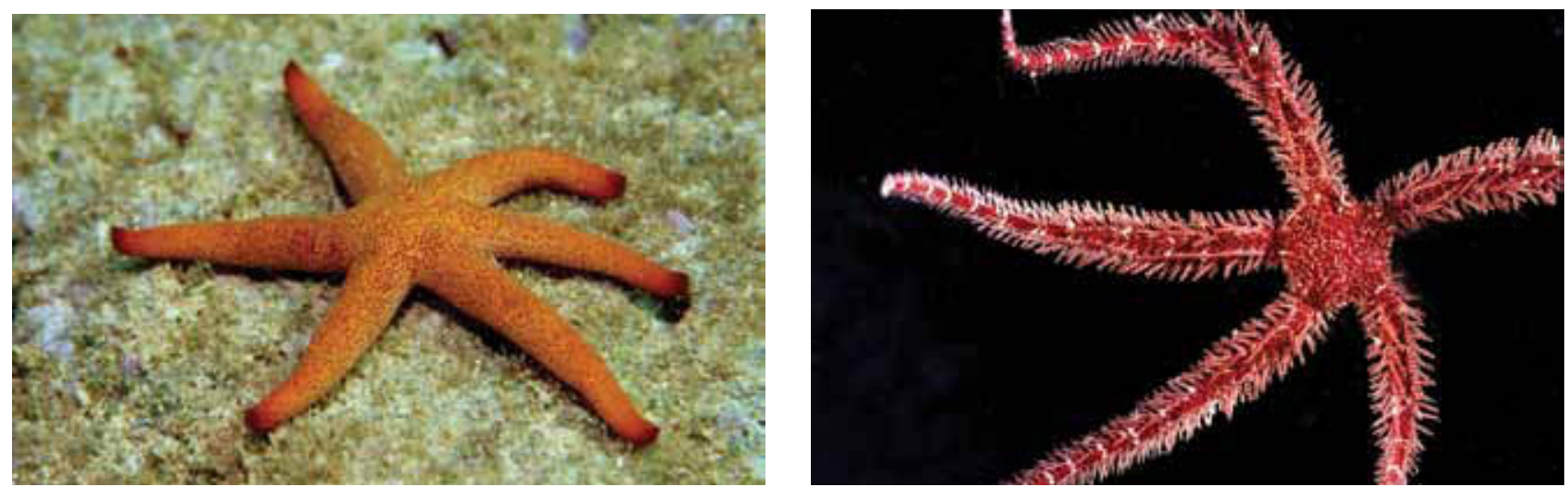

Left: Echinaster luzonicus (Gray, 1840); Right: Ophiomastix annulosa (Lamarck , 1816) (Photos: Clay Bryce)

\section{Channel Drifts:}

The channel drifts, like the platform stations were qualitative only.

Voucher specimens of unknown and noteworthy species were collected, identified at the WA Museum, registered and retained for the collections of the WA Museum.

\section{RESULTS}

Results are presented in such a way as to enable comparison with the earlier WA Museum survey (Berry, 1986; Marsh, 1986). However, a direct comparison in a quantitative sense is problematical as the methodology and effort between the surveys differ.
52 echinoderm species from the classes Asteroidea, Echinoidea and Holothuroidea were recorded during the present survey (2006), which is $71 \%$ of the species from the same classes recorded by Marsh (1986). Table 1 highlights the differences in the number of stations surveyed between the 2006 report and corresponding reefs from the 1986 publication data. The difference in effort and collection opportunity portrayed in Table 1 is reflected by the variability within and between the reefs for the two survey periods.

However, combining the number of stations for each reef system (Figure 1) a clearer indication of collecting effort can be determined. For example, 20 sampling stations were recorded in the data published in 1986 for Clerke Reef (Rowley Shoals). When this is added to the two stations at Mermaid

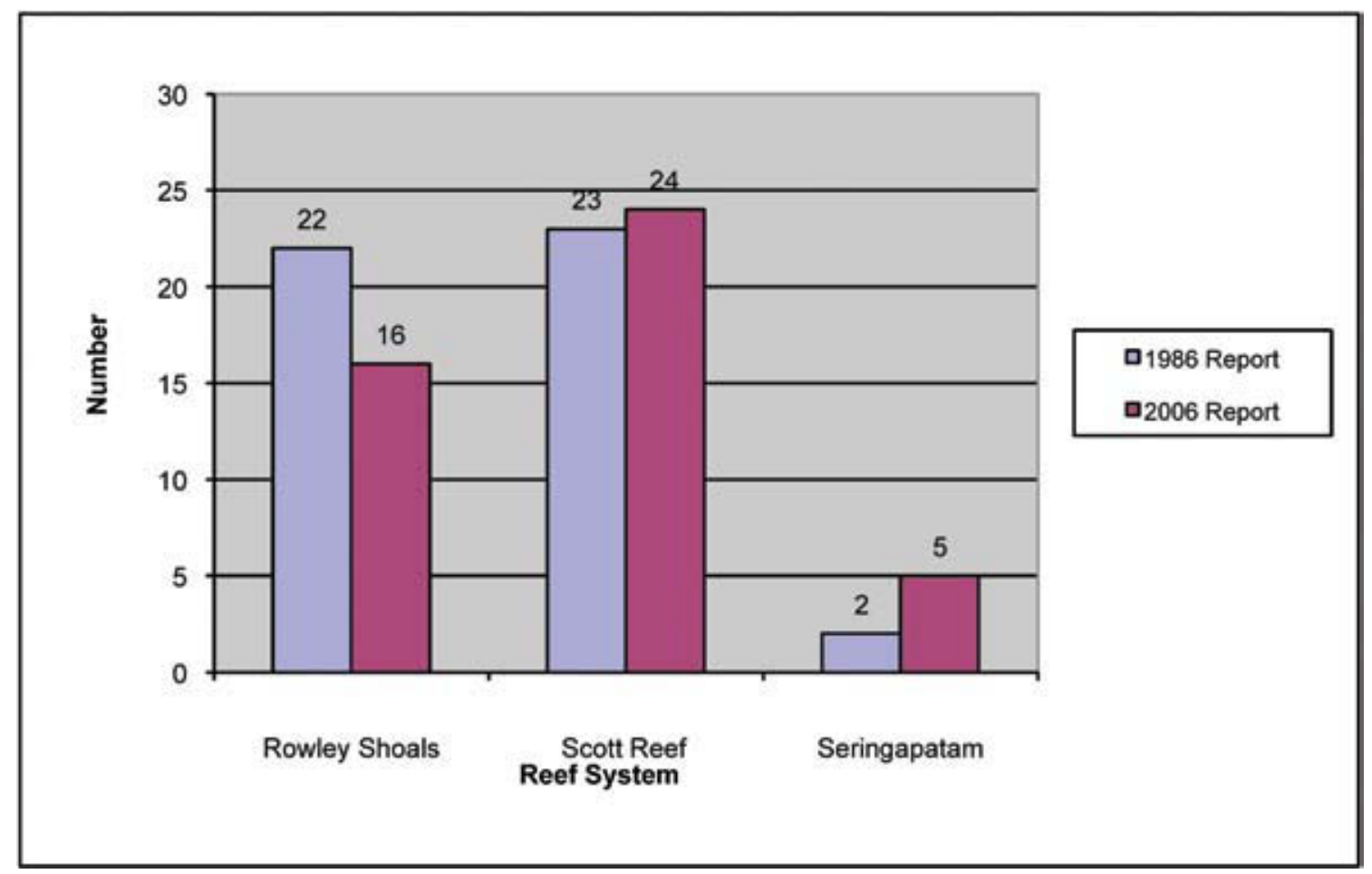

Figure 1 Station comparison between systems for 1986 and 2006 reports 

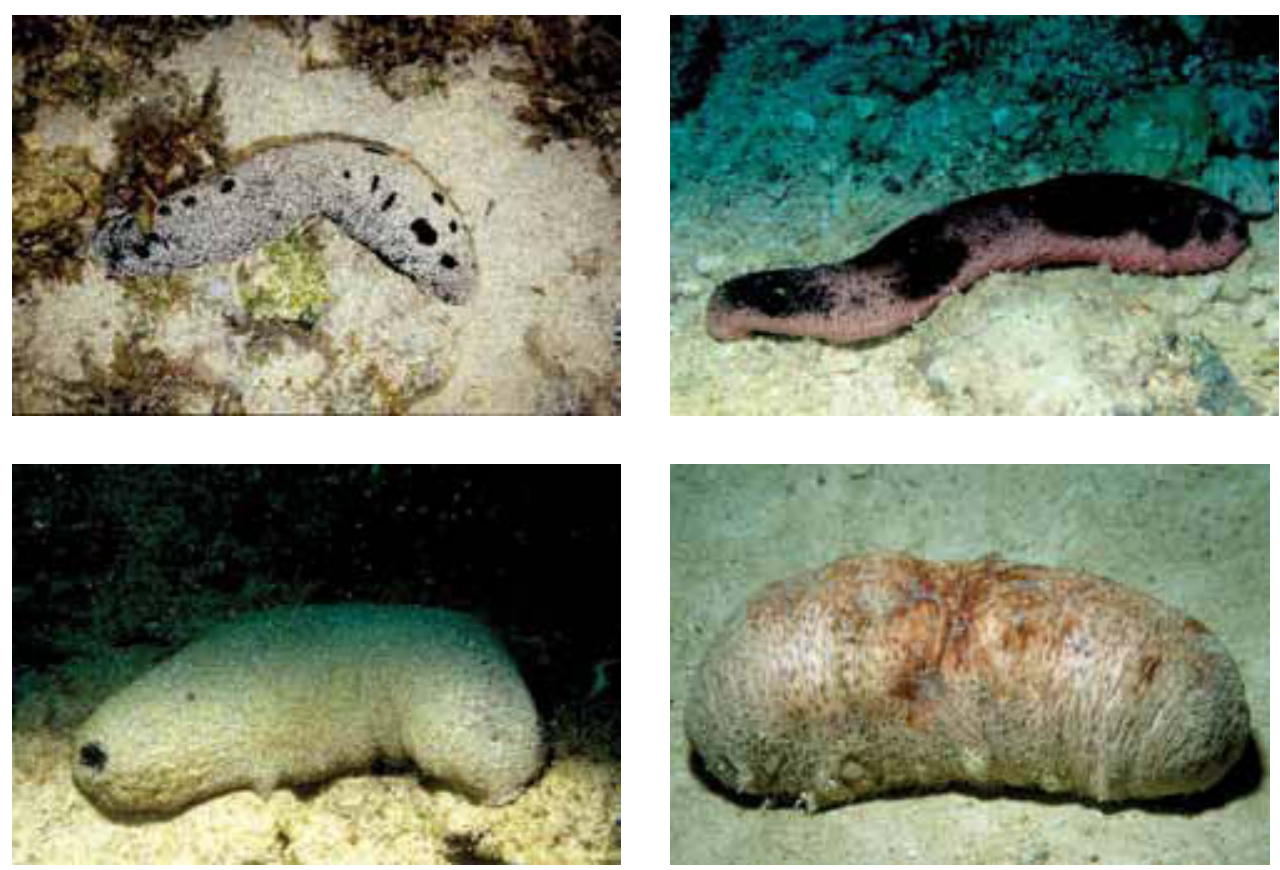

Clockwise From Top Left: Holothuria atra Jaeger, 1833; Holothuria edulis lesson, 1830; Holothuria whitmaei (Selenka, 1867); Holothuria fuscogilva Cherbonnier, 1980. (Photos: Clay Bryce)

Reef (Rowley Shoals), the only other reef sampled, and then compared to the 16 Mermaid Reef stations from the 2006 survey a more meaningful coverage of collecting opportunity is observed. A station breakdown of the various reefs visited for the report of 2006 and 1986 publication is provided in Table 1 and relates directly to Figure 1.

A complete list of species' occurrence at each atoll is shown in Table 2, which also lists previous records. A limited list of Ophiuroidea (20 species) is also provided within this table. A breakdown by atoll of the 52 species is presented in Figure 2.

From Figure 2 it can be seen that Mermaid Reef and South Scott Reef have a significantly higher number of total recorded species and correspondingly similar unique species component to the other two atolls. However, Mermaid Reef has a similar geographical shape and habitat diversity to that of North Scott Reef and Seringapatam, while South Scott Reef is large with a greater range of habitats.

\section{Asteroidea}

In Marsh (1986), 17 species of seastars were found at Mermaid and Clerke Reefs (Rowley Shoals). Of these 10 were found in 2006 plus four additional species. In the 1986 publication, 19 species were recorded from Scott (north and south atolls) and Seringapatam Reefs, of these 11 were found in 2006 plus two new records including a possible undescribed species. The newly recorded species are Cistina columbiae Gray, 1840, Aquilonastra anomala (H.L Clark, 1921), Indianastra sarasini (de Loriol,
1897) and Echinaster callosus Marenzeller, 1895 from Mermaid Reef and Celerina sp. and Cistina columbiae from South Scott Reef. Echinaster callosus is a new record for Western Australia. From North Scott Reef seven species were found in 2006 with no new records. Eight species were found at Seringapatam Reef in 2006, with no new records.

\section{Echinoidea}

In the 1986 publication, 14 species of echinoids were recorded from Rowley Shoals; of these six were recorded at Mermaid Reef in 2006 plus one new record, Nacospatangus (Pseudomaretia) alta (A. Agassiz, 1863), which is known from Indonesia. From Scott and Seringapatam Reefs 19 species of echinoid were recorded in the 1986 publication, of these only seven species were found in 2006 at the same reefs. From North Scott there was one new record, Temnotrema elegans Mortensen, 1918 and a possible new species, cf. Cyrtechinus sp.

Figures 3 and 4 demonstrate similar trends for the Asteroidea and Echinoidea in that Mermaid and South Scott Reefs are similar in having high species abundance but show a reduction for North Scott and Seringapatam Reefs. The species diversity is consistent across the reefs except for Seringapatam Reef. This low count is due to limited collecting.

\section{Holothuroidea}

In the 1986 publication, 23 species of holothurians were recorded from the Rowley Shoals of which 12 were found at Mermaid Reef in 2006. From Scott and Seringapatam Reefs 26 species were cited in 


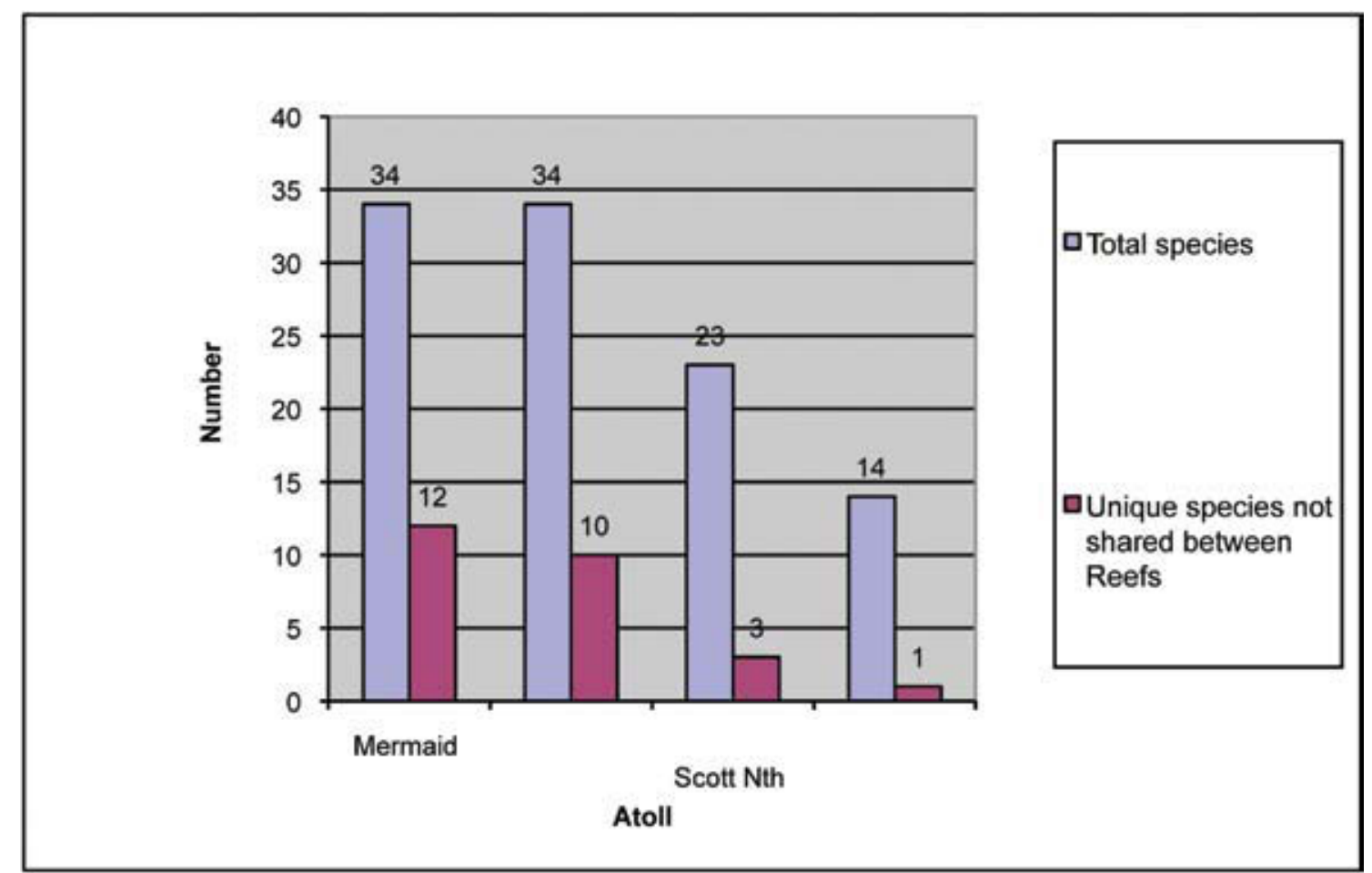

Figure 2 Comparison of the total and unique species of targeted echinoderms from each atoll (2006 Survey)

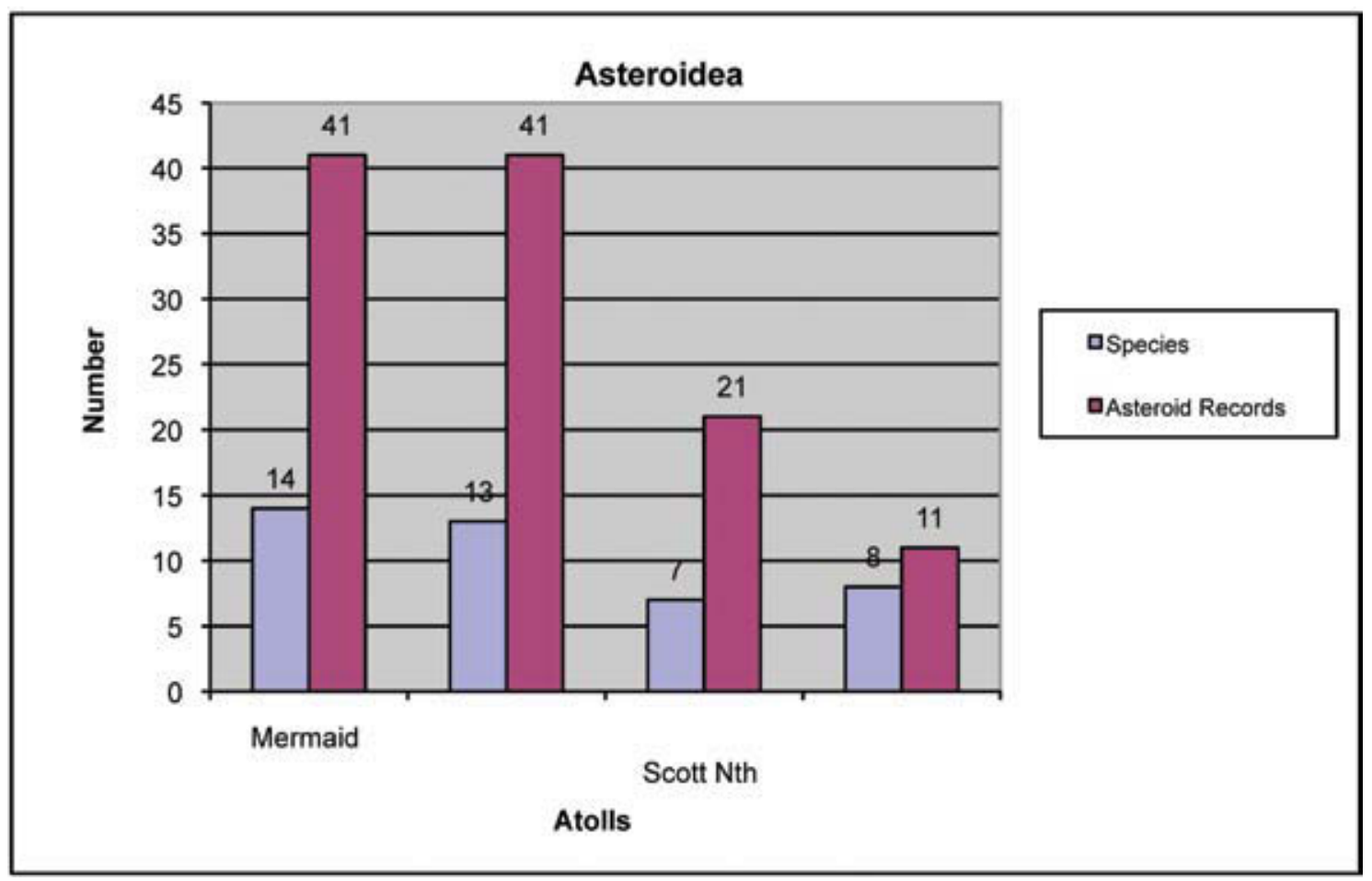

Figure 3 Number of Asteroidea species recorded by Atoll (2006 Survey) 


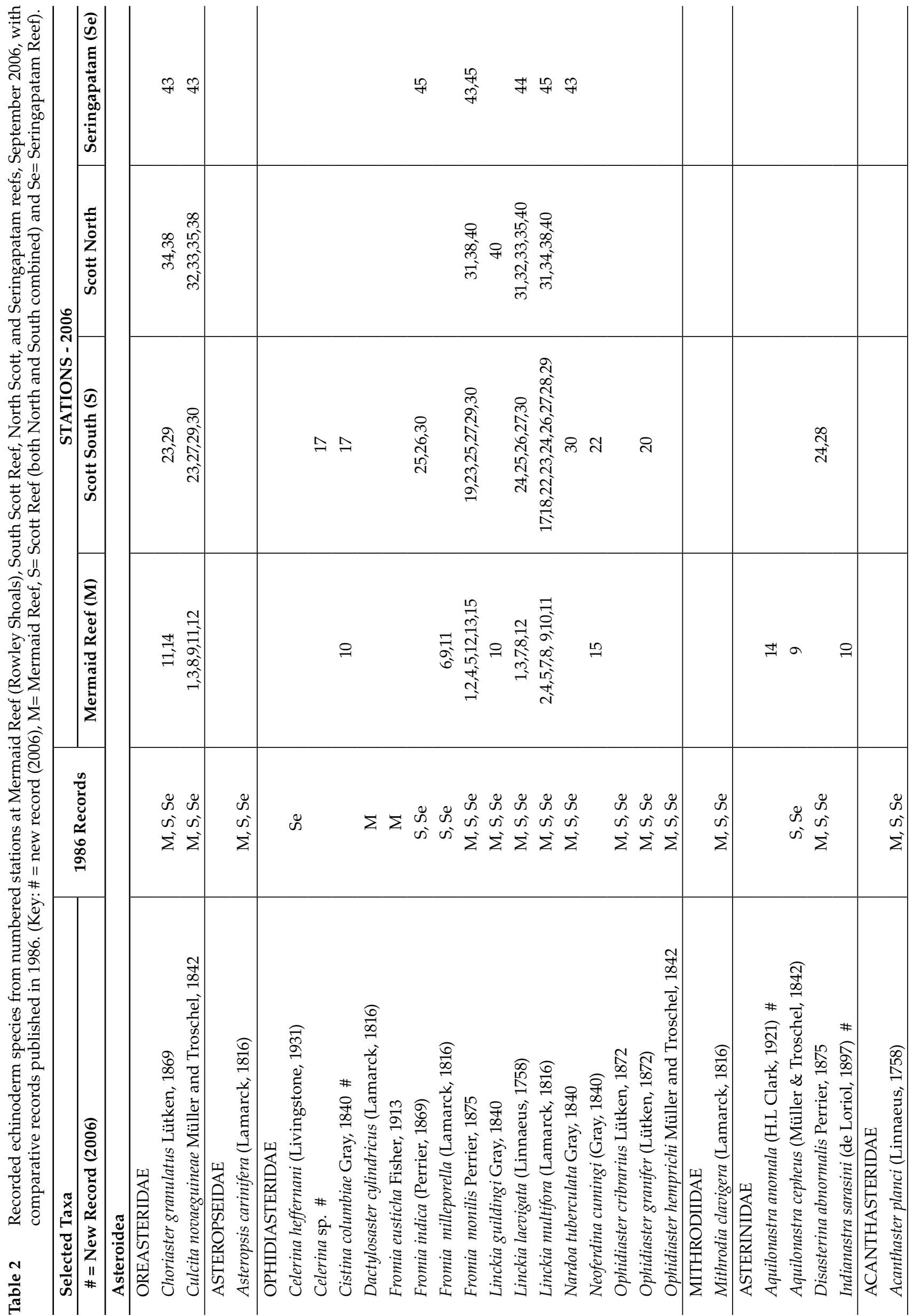




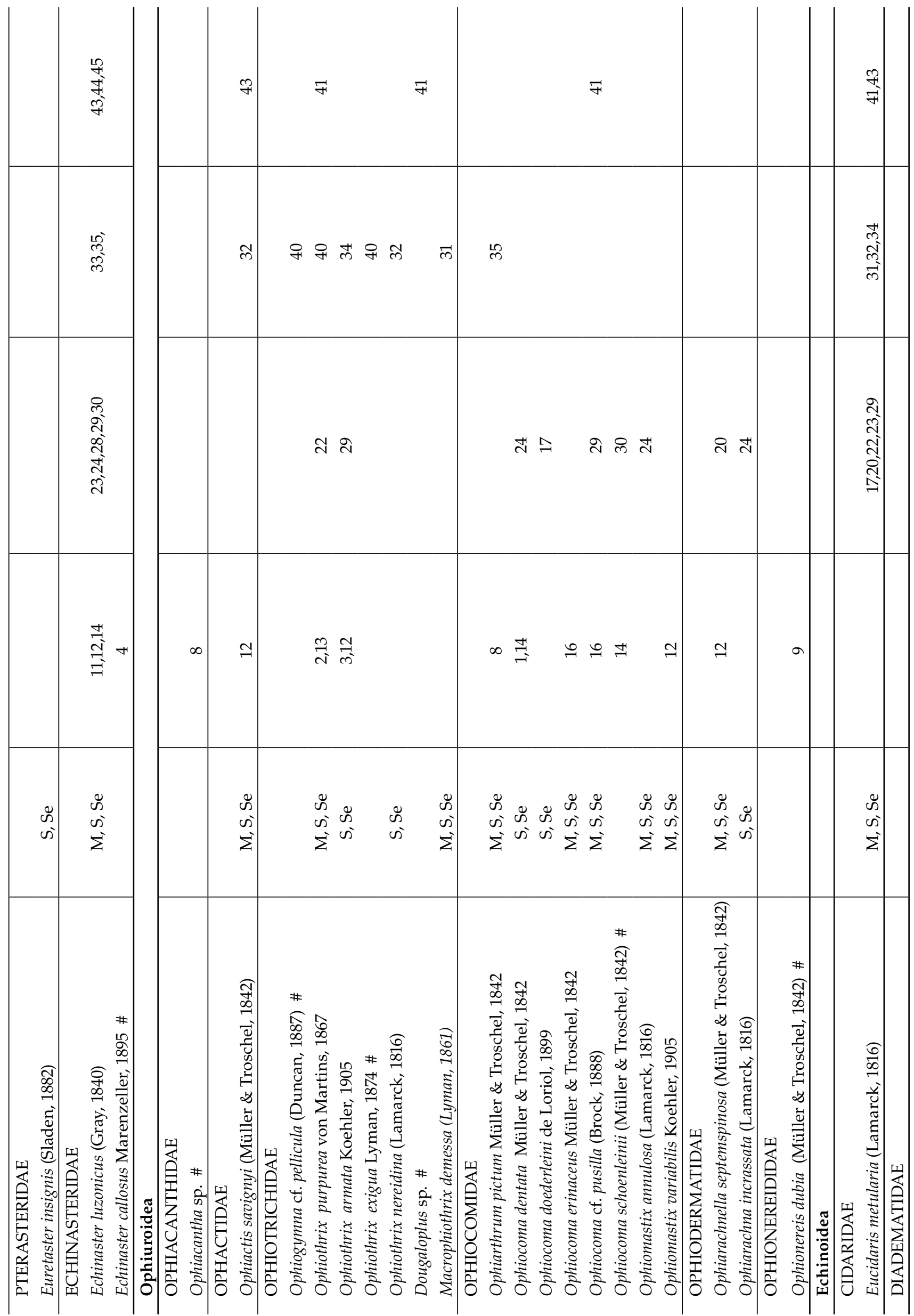




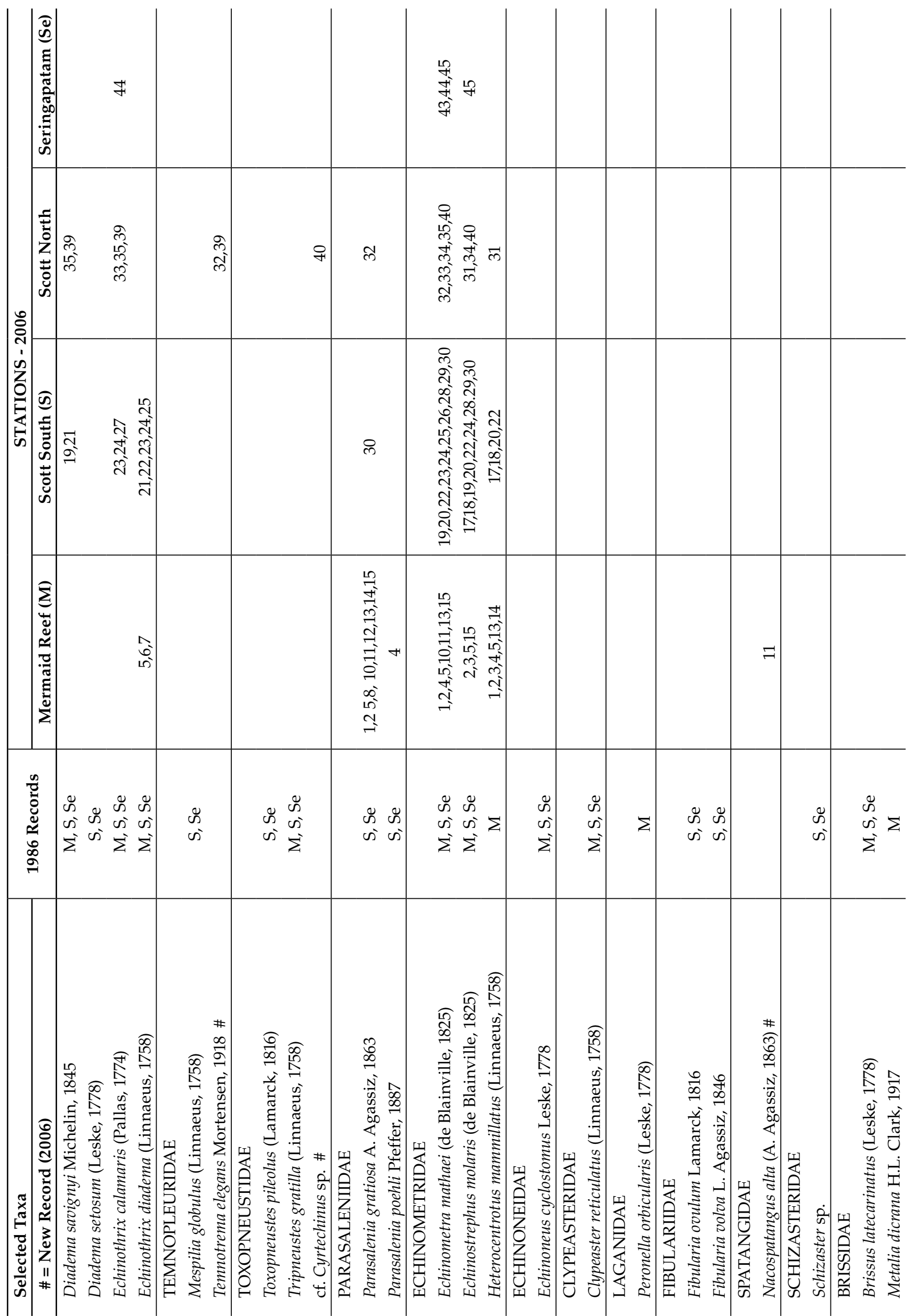




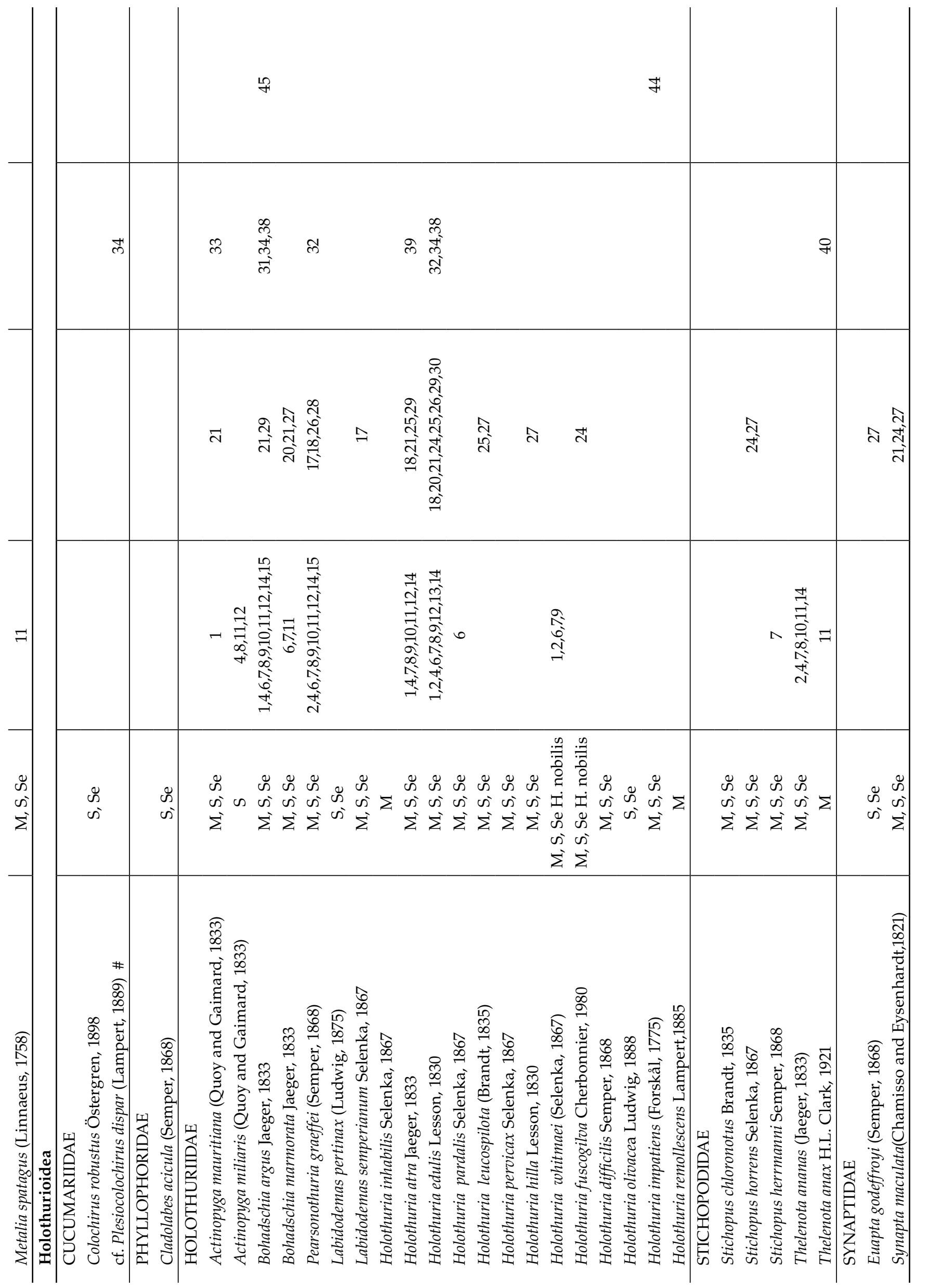




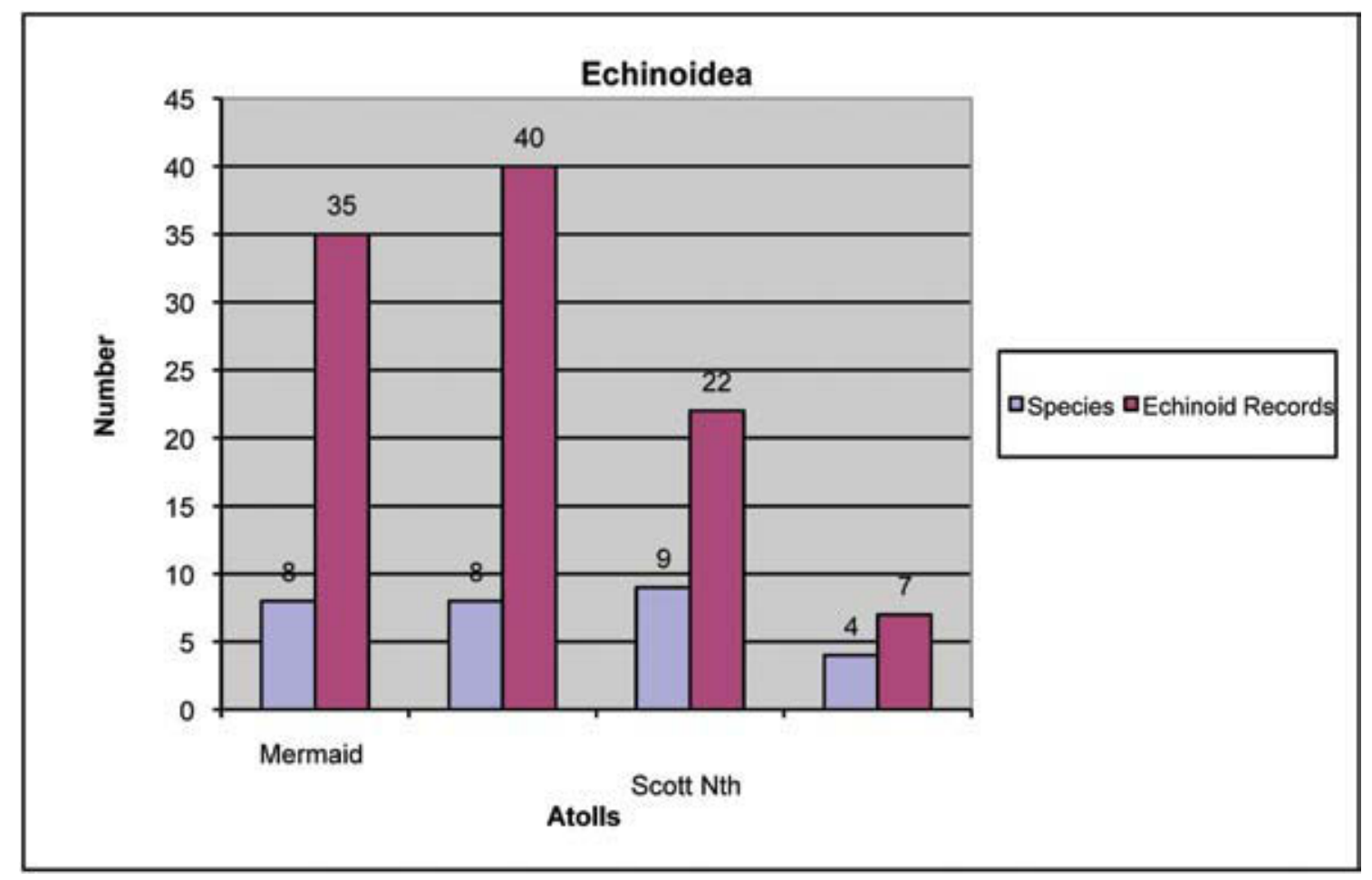

Figure 4 Number of Echinoidea species recorded by Atoll (2006 Survey)

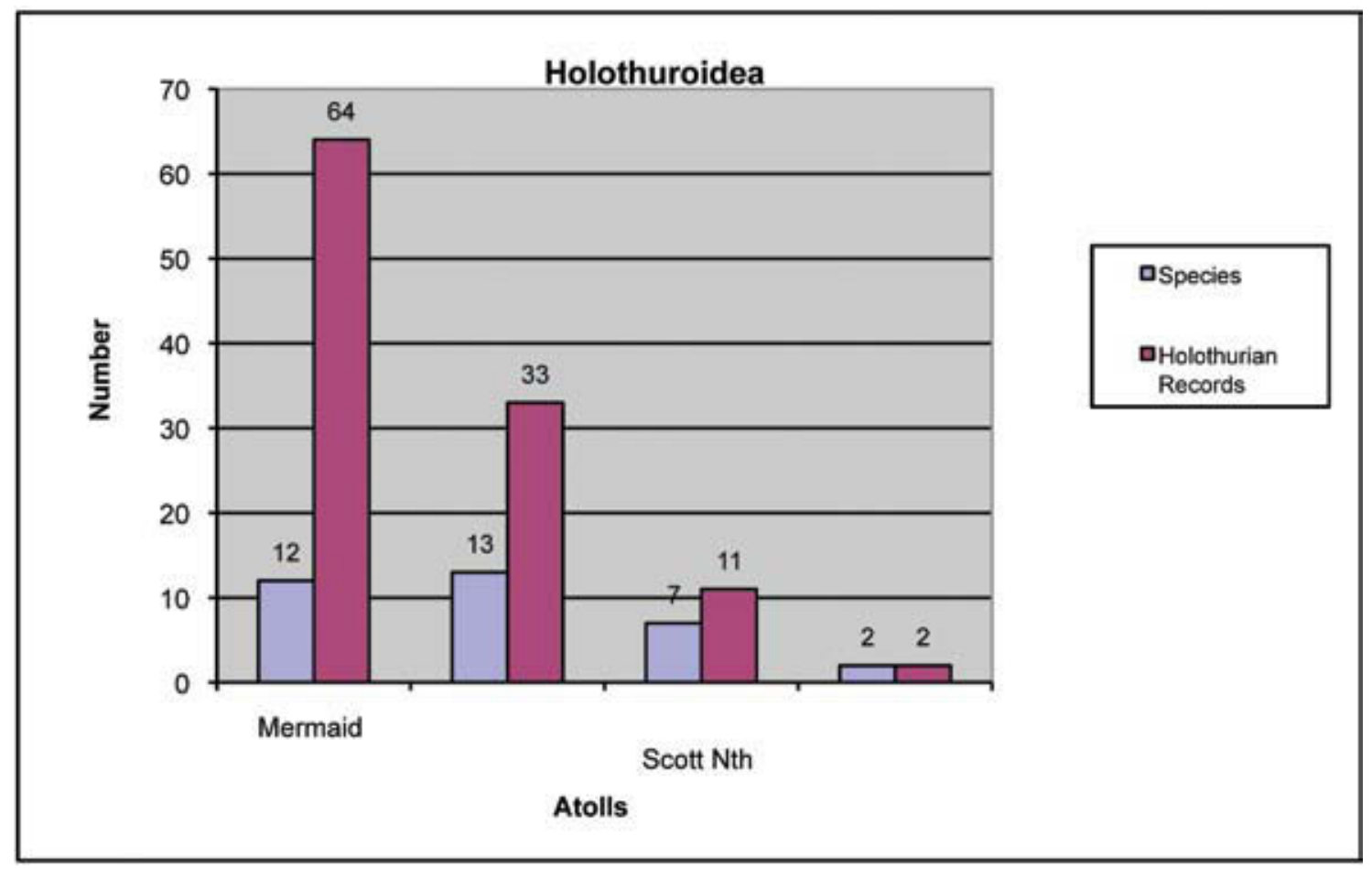

Figure 5 Number of Holothuroidea species recorded by Atoll (2006 Survey) 

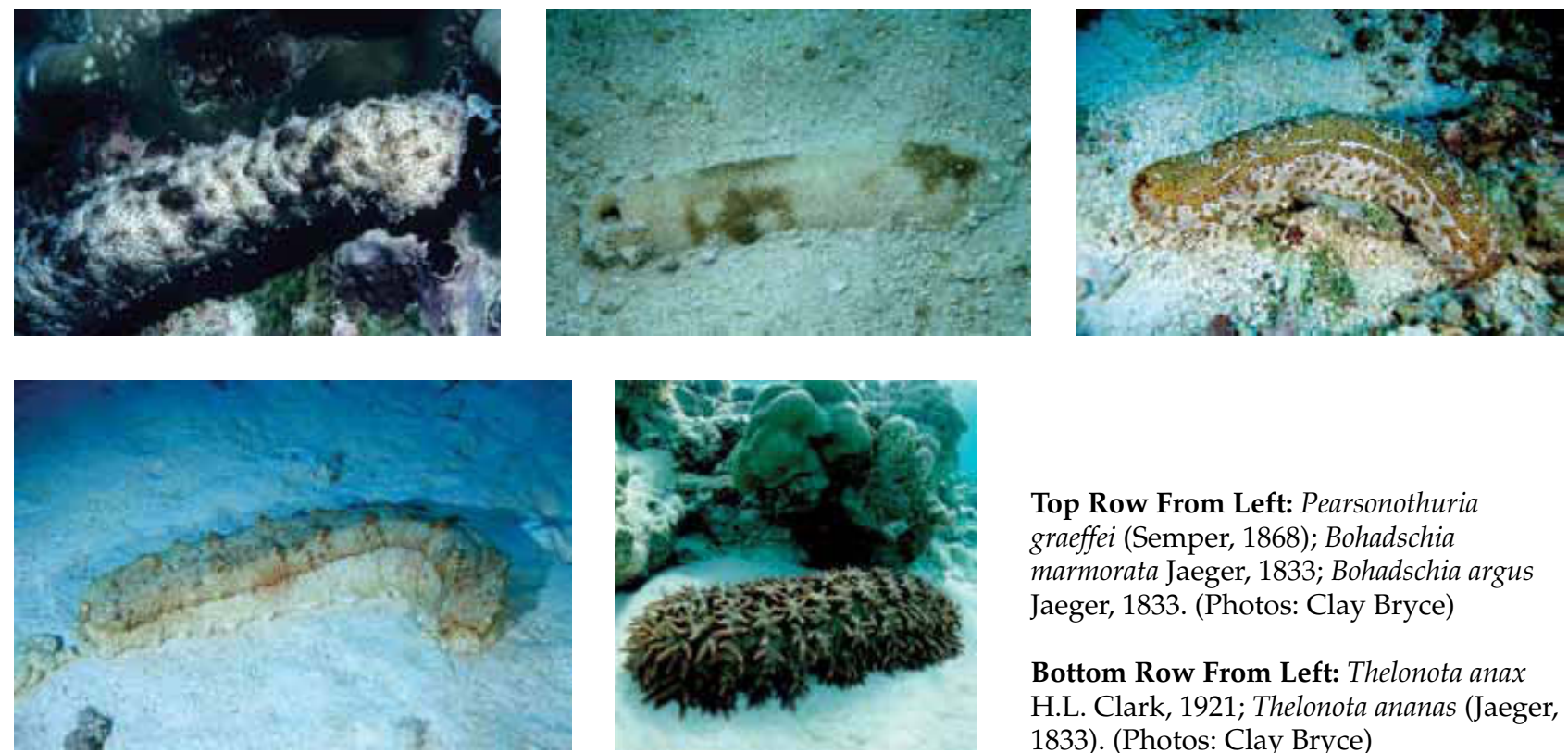

Top Row From Left: Pearsonothuria graeffei (Semper, 1868); Bohadschia marmorata Jaeger, 1833; Bohadschia argus Jaeger, 1833. (Photos: Clay Bryce)

Bottom Row From Left: Thelonota anax H.L. Clark, 1921; Thelonota ananas (Jaeger, 1833). (Photos: Clay Bryce)

the 1986 publication, of these 13 were found at South Scott Reef, seven at North Scott Reef and two at Seringapatam Reef. A single new record, cf. Plesiocolochirus dispar (Lampert, 1889) from North Scott Reef was collected.

Figure 5 illustrates that the number of individual holothurians from Mermaid Reef to be the highest (64), but South Scott (33), North Scott (11) and Seringapatam Reefs (2) are extremely reduced in numbers.

\section{Ophiuroidea}

Brittle stars were not targeted during the 2006 survey but were collected opportunistically and so are not graphed. No meaningful comparisons can be made with the 1986 publication results of the survey. However, ophiuroids are the most speciose group found on coral reefs. In Marsh (1986) 28 species were collected from the Rowley Shoals (all three atolls) and 38 from Scott and Seringapatam Reefs. In 2006 twelve species were collected at Mermaid Reef, nine at South Scott, eight at North Scott and four at Seringapatam. In total 20 species were collected during the 2006 survey. Of note are six species, Ophiacantha sp., Ophiocoma schoenleini (Müller and Troschel, 1842), Ophionereis dubia (Müller and Troschel, 1842), Ophiothrix exigua Lyman, 1874, Dougaloplus sp. and Ophiogymna pellicular (Duncan, 1887) recorded for the first time from the northwest atolls (Table 2).

\section{DISCUSSION}

The reduction in echinoderm records (Figure 3, 4 and 5) in North Scott and Seringapatam Reefs when compared to Mermaid Reef, a similar sized atoll, and South Scott Reef, a close neighbour, is noteworthy. The reduction could be due to a number of factors. Seringapatam and North Scott Reefs were heavily damaged by two bleaching events in 1998 and 2003 (Rees, 2003) and by the subsequent erosive cyclonic damage of Cyclone Fay during the 2003 /2004 cyclone season. Mermaid Reef, being of a comparable size to North Scott and Seringapatam Reefs but $400 \mathrm{~km}$ south, only suffered minimal damage. South Scott Reef also suffered the same damage as North Scott and Seringapatam, but covers a larger area, has deeper lagoonal waters with better flushing due to its open north end and a more diverse range of habitats.

The bleaching and cyclonic events may also explain the numbers of seastars and echinoids. Under-sampling for Seringapatam Reef would also have been a cause in the low numbers recorded there. Seringapatam Reef has always had the least sampling devoted to it by all expeditions to the region.

Mermaid Reef has the highest numbers of holothurians but stocks at South Scott, North Scott and Seringapatam have declined significantly. This reflects the added factor of fishing pressure by Indonesian fishers under the AustralianIndonesian government's Memorandum of Understanding (MOU74). This MOU allows traditional fishers to utilise the waters of Scott and Seringapatam Reefs, but not Mermaid Reef. As can be seen, the bêche-de-mer (commercial holothurian) stocks of South Scott, North Scott and Seringapatam Reefs have declined significantly to an extremely low level (Berry, 1986; Skewes, 1999; Bryce, 2006) where oligospermy may become a serious factor in slowing population regrowth.

Only seven holothurians, representing three commercial species were found over 21 transects on Scott (North and South) and Seringapatam 
Reefs. In contrast, Mermaid Reef had 49 individual holothurians representing 9 species over 16 transects.

The highly sought after Holothuria whitmaei (Selenka, 1867) (black teat fish) and H. fuscogilva Cherbonnier, 1980 (white teat fish) were notably absent in over 21 transects at Scott and Seringapatam Reefs. There was only one sighting for these two species off the transects and this was a juvenile $H$. fuscogilva at platform station 24 . Both these species have a high commercial value but have late sexual maturity and low to medium fecundity resulting in rapid depletion of stocks and slow replenishment after overfishing (Uthicke et al., 2004, 2004a). South Scott and North Scott Reefs exhibit the diversity but not the numbers of this most necessary reef inhabitant. The figures point to near total population collapses at all reefs, other than Mermaid Reef, for this group of echinoderms. In contrast, the holothurian stocks at Mermaid Reef are very much greater with good populations of the above two species.

\section{CONCLUSION}

The results of this survey show considerable difference in the echinoderm populations between the reefs. The Mermaid Reef far tot eh south has escaped much of the recent influences of fishing, bleaching events and cyclonic activity (Rees, 2003). Allowing for the differences in methodology and effort between the WA Museum's published report of 1986 (Berry, 1986) and this survey, the echinoderm diversity and numbers for Mermaid Reef appear to be very similar. The same cannot be said, however, for Scott and Seringapatam Reefs. These once pristine oceanic atolls, which form part of a unique habitat off Western Australia's coast (Berry, 1986) appear to be in a state of decline. The collapse of the holothurian populations may have a detrimental effect on reef nutrient loads and general lagoonal turbidity.

The possibly undescribed species of seastar at South Scott Reef is of significance. It has been placed in the genus Celerina with further work needed to clarify its species status.

As with much of the Western Australian coastline, new species are still being found and with developments in marine exploration technology improving more will undoubtedly be found. It is, therefore, imperative that the reefs and their inhabitants, which are Australian assets, should be managed with due diligence.

\section{ACKNOWLEDGEMENTS}

The authors would like to thank the owners and crew of the Kimberley Quest for their assistance during the expedition. We also thank Mark Salotti for his technical support and Yuki Konishi who thoroughly crosschecked data entry. Valuable input and suggestions from Dr. John Keesing and Dr. Tim O'Hara are also greatly appreciated.

\section{REFERENCES}

Berry, P.F. (ed.). (1986): Faunal surveys of the Rowley Shoals, Scott Reef and Seringapatam Reef, Northwestern Australia. Records of the Western Australian Museum, No 25: 27-35. Western Australian Museum, Perth.

Bryce, C.W. (2006). Invertebrate Marine Resources of Scott and Seringapatam Reefs (and Browse Island). In URS Report on Environmental Surveys undertaken at Scott Reef in February 2006. (Unpublished Report) Western Australian Museum, Perth.

Bryce, C.W and Marsh L.M (2006). A survey of selected Echinodermata (Asteroidea, Echinoidea and Holothuroidea) of Mermaid (Rowley Shoals), Scott and Seringapatam Reefs, north western Australia. In A Marine Biological Survey of Mermaid Reef (Rowley Shoals), Scott and Seringapatam Reefs. A Preliminary Report. Marine Survey Team, Aquatic Zoology. Western Australian Museum, Perth, Unpublished. 136 pp.

Marsh. L.M. (1986). Part VI Echinoderms. In Berry. P.F. (ed) Faunal Surveys of the Rowley Shoals, Scott Reef, and Seringapatam Reef, North-western Australia. Records of the Western Australian Museum, Supplement. 25: 41-57. Western Australian Museum, Perth.

Rees, M., Colquhoun, J., Smith, L. and Heyward, A. 2003. Survey of Trochus, holothurian, giant clams and the coral communities at Ashmore Reef, Cartier Reef and Mermaid Reef, Northwestern Australia. Report to Department of the Environment and Heritage, Canberra. 64p.

Skewes, T.D., Dennis, D.M., Jacobs, D.R., Gordon, S.R., Taranto, T.J., Haywood, M., Pitcher, C.R., Smith, G.P., Milton and D., Poiner, I.R. 1999. Survey and stock size estimates of the shallow reef ( $0-15 \mathrm{~m}$ deep) and shoal area (15-50m deep) marine resources and habitat mapping within the Timor Sea MOU74 box. Volume 1: Stock estimates and stock status. CSIRO. Marine Resources of the MOU74 Box, July, 1999.

Smith, L.D., Rees, M., Colquhoun, J. and Heyward, A. (2005). Survey of bêche-de-mer and Trochus populations at Ashmore Reef: baseline survey. The Beagle, Records of the Museum and Art Galleries of the Northern Territory Supplement 1: 177-183.

Uthicke, S., O'Hara, T.D. and Byrne, M. (2004). Species composition and molecular phylogeny of the IndoPacific teatfish (Echinodermata: Holothuroidea) bêche-de-mer fishery. Marine and Freshwater Research 55: 837-848.

Uthicke, S, Welch, D., and Benzie, J.A.H. (2004a). Slow growth and lack of recovery in overfished holothurians on the Great Barrier Reef: Evidence from DNA fingerprints and repeated large-scale surveys. Conservation Biology 18, 34-39 